
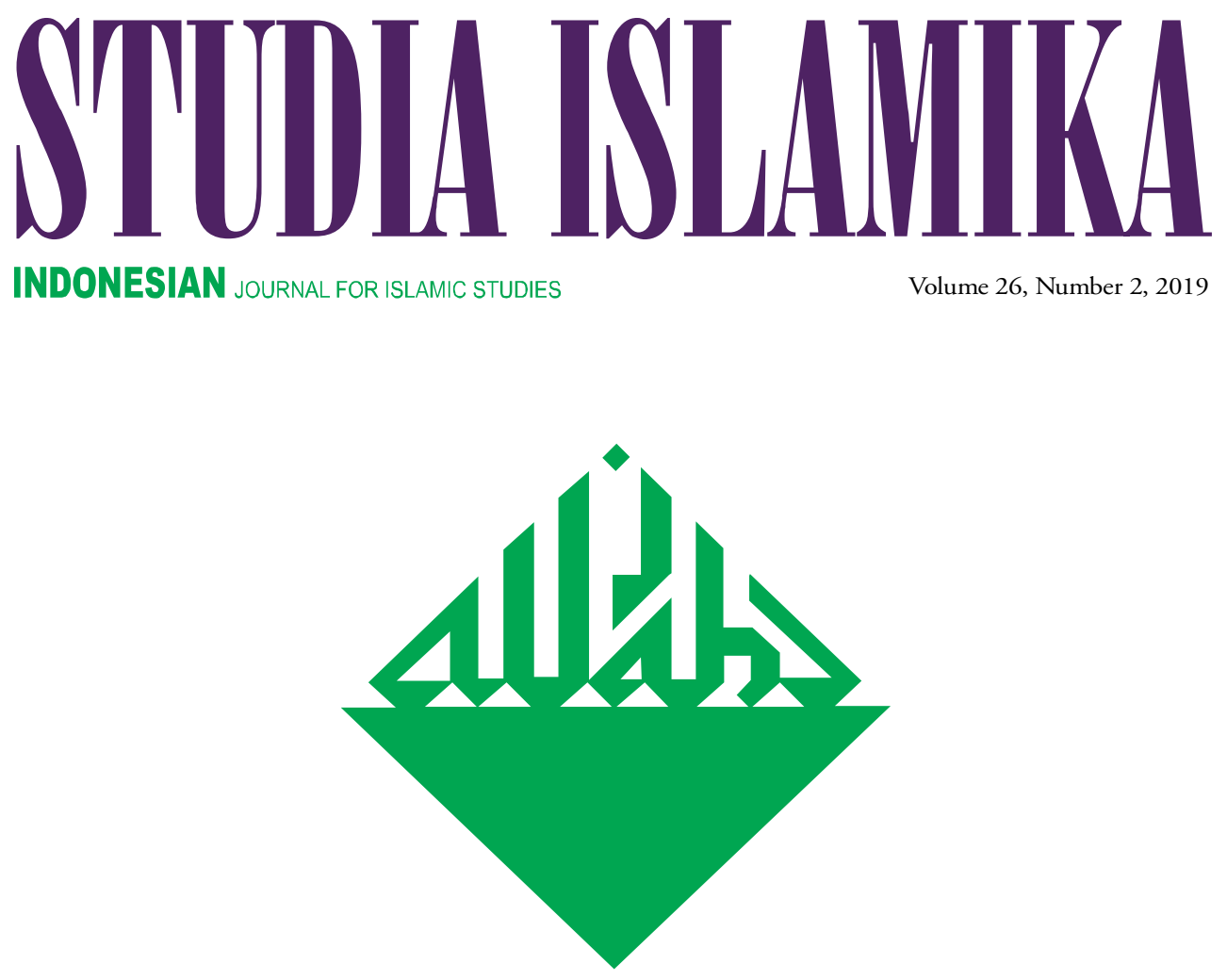

Bureaucratizing Sharia in Modern Indonesia: The Case of ZaKat, WaQf and Family LaW Asep Saepudin Jahar

Qur'anic Exegesis for Commoners:

A Thematic Sketch of Non-Academic TAFSIR WORKS IN INDONESIA

Mu’ammar Zayn Qadafy

Being Muslim in a Secular World:

INDONESIAN FAMILIES IN WASHINGTON DC AREA Asna Husin

Explaining Religio-Political Tolerance Among Muslims: Evidence from Indonesia Saiful Mujani 
STIUDLA ISLAMIIIKA 



\section{STIDIIA ISLAVIIIKA}

Indonesian Journal for Islamic Studies

Vol. 26, no. 2, 2019

EDITOR-IN-CHIEF

Azyumardi Azra

MANAGING EDITOR

Oman Fathurahman

EDITORS

Saiful Mujani

Jambari

Didin Syafruddin

Jajat Burhanudin

Fuad Jabali

Ali Munhanif

Saiful Umam

Dadi Darmadi

Jajang Jahroni

Din Wahid

Euis Nurlaelawati

INTERNATIONAL EDITORIAL BOARD

M. Quraish Shihab (Syarif Hidayatullah State Islamic University of Jakarta, INDONESIA)

M.C. Ricklefs (Australian National University, AUSTRALIA)

Martin van Bruinessen (Utrecht University, NETHERLANDS)

John R. Bowen (Washington University, USA)

M. Kamal Hasan (International Islamic University, MALAYSIA)

Virginia M. Hooker (Australian National University, AUSTRALIA)

Edwin P. Wieringa (Universität zu Köln, GERMANY)

Robert W. Hefner (Boston University, USA)

Rémy Madinier (Centre national de la recherche scientifique (CNRS), FRANCE)

R. Michael Feener (National University of Singapore, SINGAPORE)

Michael F. Laffan (Princeton University, USA)

Minako Sakai (The University of New South Wales, AUSTRALIA)

Annabel Teh Gallop (The British Library, UK)

Syafaatun Almirzanah (Sunan Kalijaga State Islamic University of Yogyakarta, INDONESIA)

\section{ASSISTANT TO THE EDITORS}

Testriono

Muhammad Nida' Fadlan

Rangga Eka Saputra

Abdullah Maulani

ENGLISH LANGUAGE ADVISOR

Benjamin J. Freeman

Daniel Peterson

Batool Moussa

ARABIC LANGUAGE ADVISOR

Tb. Ade Asnawi

Ahmadi Usman

COVER DESIGNER

S. Prinka 
STUDIA ISLAMIKA (ISSN 0215-0492; E-ISSN: 2355-6145) is an international journal published by the Center for the Study of Islam and Society (PPIM) Syarif Hidayatullah State Islamic University of Jakarta, INDONESIA. It specializes in Indonesian Islamic studies in particular, and Southeast Asian Islamic studies in general, and is intended to communicate original researches and current issues on the subject. This journal warmly welcomes contributions from scholars of related disciplines. All submitted papers are subject to double-blind review process.

STUDIA ISLAMIKA has been accredited by The Ministry of Research, Technology, and Higher Education, Republic of Indonesia as an academic journal (Decree No. 32a/E/KPT/2017).

STUDIA ISLAMIKA has become a CrossRef Member since year 2014. Therefore, all articles published by STUDIA ISLAMIKA will have unique Digital Object Identifier (DOI) number.

STUDIA ISLAMIKA is indexed in Scopus since 30 May 2015.

Editorial Office:

STUDIA ISLAMIKA, Gedung Pusat Pengkajian

Islam dan Masyarakat (PPIM) UIN Jakarta,

Jl. Kertamukti No. 5, Pisangan Barat, Cirendeu,

Ciputat 15419, Jakarta, Indonesia.

Phone: (62-21) 7423543, 7499272, Fax: (62-21) 7408633;

E-mail: studia.islamika@uinjkt.ac.id

Website: http://journal.uinjkt.ac.id/index.php/studia-islamika

Annual subscription rates from outside Indonesia, institution: US\$ 75,00 and the cost of a single copy is US\$ 25,00; individual: US\$ 50,00 and the cost of a single copy is US\$ 20,00 . Rates do not include international postage and handling.

Please make all payment through bank transfer to: PPIM, Bank Mandiri KCP Tangerang Graha Karnos, Indonesia, account No. 101-00-0514550-1 (USD),

Swift Code: bmriidja

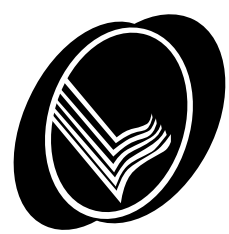

Harga berlangganan di Indonesia untuk satu tahun, lembaga: Rp. 150.000,-, harga satu edisi Rp. 50.000,-; individu: Rp. 100.000,-, harga satu edisi Rp. 40.000,-. Harga belum termasuk ongkos kirim.

Pembayaran melalui PPIM, Bank Mandiri KCP Tangerang Graha Karnos, No. Rek: 128-00-0105080-3 


\section{Table of Contents}

\section{Articles}

207 Asep Saepudin Jahar

Bureaucratizing Sharia in Modern Indonesia:

The Case of Zakat, Waqf and Family Law

247 Mu'ammar Zayn Qadafy

Qur'anic Exegesis for Commoners:

A Thematic Sketch of Non-Academic

Tafsir Works in Indonesia

277 Asna Husin

Being Muslim in a Secular World:

Indonesian Families in Washington DC Area

319 Saiful Mujani

Explaining Religio-Political Tolerance

Among Muslims: Evidence from Indonesia

353 Muhamad Arif

Taqlīd Ngunya li muslimī Pegayaman bi Bali:

Taṭbìq al-sharīah al-Islāmìyah fī baldat al-Hindūs 


\section{Book Review}

389 Endi Aulia Garadian

Para Wali Nyentrik:

Rekontekstualisasi Islamisasi di Tanah Jawa, Menantang Fundamentalisme Islam

\section{Document}

407 Abdallah

State, Religious Education, and Prevention of Violent Extremism in Southeast Asia 


\title{
Saiful Mujani \\ Explaining Religio-Political Tolerance Among Muslims: Evidence from Indonesia
}

\begin{abstract}
Once a fully free country according to Freedom House, Indonesia has declined to partly free in the last seven years, indicating that the largest Muslim democracy in the world is deconsolidating. The decrease of freedom in Indonesia is believed to be associated with intolerance toward religious minorities, specifically by Muslims toward non-Muslims. Previous studies found that Indonesians are in general intolerant. However, those studies ignore factors which have the potential to strengthen religio-polititical tolerance. My contribution is to fill this empty space by explaining the intolerance. The potential explanatory factors are political, economic, and security conditions, institutional engagement, political engagement, and democratic values. Based on a nationwide public opinion survey, this study reveals new findings about which factors are more crucial to strengthening religio-political tolerance. Muslim religiosity affects significantly and negatively religiopolitical tolerance. However, economic, political, and security conditions, institutional engagement, political engagement, democratic values, and Javanese ethnicity more significantly explain the tolerance. If these factors prevail over religion and religiosity, tolerance will improve.
\end{abstract}

Keywords: Religio-Political Tolerance, Democracy, Islam, Indonesia. 
Abstrak: Menurut Freedom House, Indonesia pernah mencapai negara bebas penuh, tapi merosot menjadi negara setengah bebas dalam tujuh tahun terakhir ini. Menurunnya kebebasan tersebut diyakini berhubungan dengan intoleransi terhadap kelompok-kelompok agama atau faham agama minoritas, secara khusus intoleransi muslim terhadap non-Muslim. Studi-studi sebelumnya sudah menemukan bahwa orang Indonesia memang tidak toleran. Tapi studi-studi tersebut mengabaikan faktor-faktor yang potensial dapat meningkatkan toleransi atau sebaliknya. Artikel ini adalah satu upaya untuk menutup kekosongan tersebut. Bertumpu pada data survei opini publiknasional tulisan ini menunjukan temuan-temuan baru mengenai faktor-faktor apa yang dapat memperkuat toleransi politik-keagamaan. Ketaatan beragama di kalangan Muslim memang memperlemah toleransi politik-keagamaan, tapi kondisi elonomi-politik dan keamanan, sikap peduli pada institusi, peduli politik, komitmen terhadap nilainilai demokrasi, dan warga suku bangsa Jawa memperkuat toleransi tersebut. Kalau faktor-faktor ini mengalahkan faktor agama dan ketaatan beragama maka toleransi politik-keagamaan di Indonesia akan membaik.

Kata kunci: Toleransi Politik-Keagamaan, Demokrasi, Islam, Indonesia.

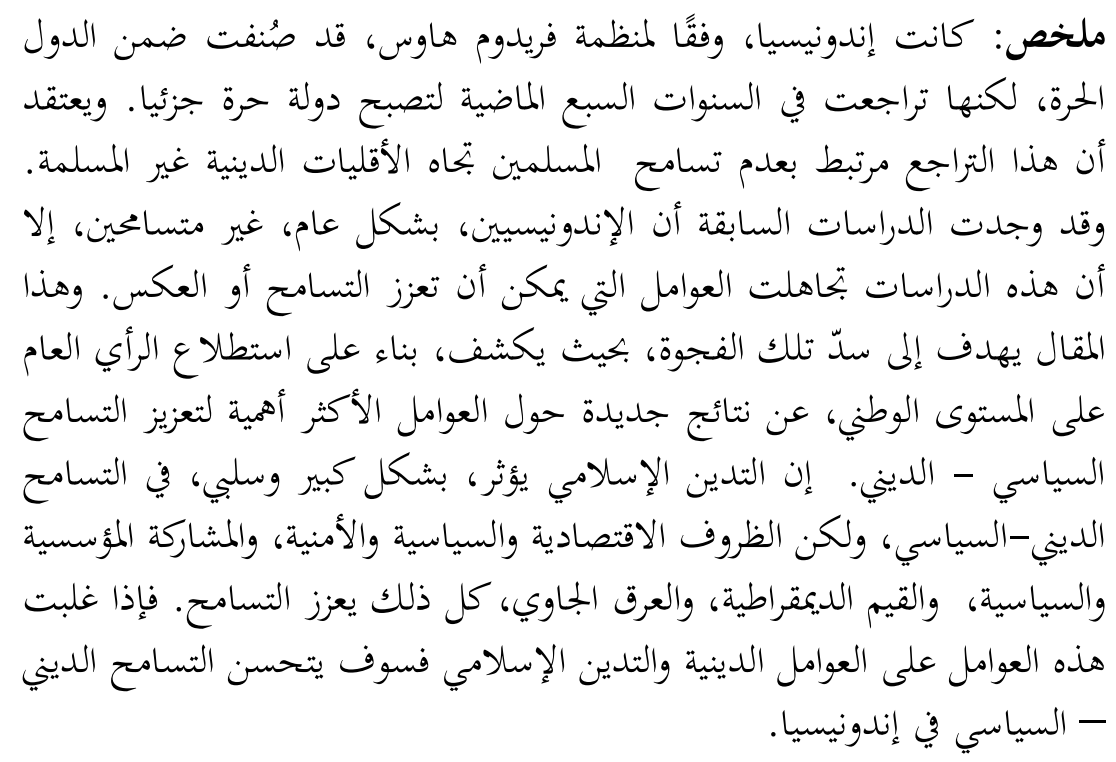

الكلمات المفتاحية: التسامح الديني-السياسي، الديمقراطية، الإسلام، إندونيسيا. 


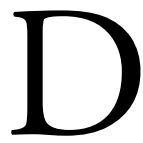

emocratic deconsolidation, measured by the decline of freedom, has occurred in Indonesia during the last seven years (Freedom House 2018). ${ }^{1}$ From 2006-2012, Indonesian democracy was considered consolidated, as the country was labeled fully free in both political rights and civil liberties, the two key indicators used by Freedom House, the most respected international evaluator of nation-state democracy. Deconsolidation has occurred as civil liberties, especially respect for minority rights, have declined, from fully free to partly free. Minority rights specifically refers to religious freedom or religious tolerance. Several other assessments of Indonesian democratic performance are consistent with Freedom House (Aspinall and Warburton 2017; Hadiz 2017; Liddle and Saiful Mujani 2013; Mietzner 2018).

Indonesian democratic deconsolidation has occurred as religious freedom or religious tolerance has deteriorated. There are many instances of deterioration, for example mass violence against Islamic minorities such as the Ahmadiyah and Syi'ah, in which the state has failed in its responsibility to protect them; also many church burnings, with no guarantee to rebuild the destroyed churches (Tempo.co 2018). The most notorious case of religious intolerance is the conviction for blasphemy of former Jakarta governor Basuki Tjahaja Purnama. A Christian, he was alleged by a Muslim group to have blasphemed against Islam, a crime in Indonesia, then arrested by the police, charged by the state prosecutor, convicted in court, and finally sentenced to jail for several years. During this time he was unable to campaign effectively for his reelection as governor in 2017 (BBC News Indonesia 2017).

Civil liberty, specifically religious tolerance, is a crucial issue threatening a country's democratic consolidation. Electoral democracy, characterized by regularly held free elections, is not sufficient for democratic consolidation. As pointed out by Dahl (1971), the lack of tolerance, specifically of state guarantees of minority rights, has been the cause of failure for many democracies. According to the foremost scholars of democratic political culture, mutual trust and tolerance are required in addition to formal political participation to make democracy work and remain stable (Almond and Verba 1963).

Indonesian democratization is quite recent, dating from only 1998, when the dictator Suharto stepped down after more than three decades in power. It is still understudied, especially in terms of political or religious tolerance. Some analysts critique Indonesian democracy as an instance of 
"tolerance without liberalism" (Menchik 2016; Menchik and Pepinsky 2018). My goal in this research is to contribute to scholarly understanding of this issue, specifically to explain the religio-political tolerance toward non-Muslim minorities in the world's largest Muslim country.

The concept of tolerance refers to attitudes and behavior of a majority toward minority rights. It initially referred to religious conflicts and state persecution against religious minorities in $17^{\text {th }}$ century Europe. John Locke's A Letter Concerning Toleration (Locke and Shapiro 2003), originally published in 1689 , expressed early concern with this issue.

The meaning of tolerance in this study is "the ability or willingness to tolerate the existence of opinions or behavior that one dislikes or disagrees with" (Oxford Dictionaries Tolerance n.d.). An often-quoted definition of tolerance in political studies is "willingness to 'put up with" those things one rejects or opposes" (Sullivan, Piereson, and Marcus 1982, 2). Further, tolerance implies "respecting and considering the humanity of a person as more important than any idea or ideal we or they may hold" (Williams and Jackson 2015, 2).

In Indonesia, Muslims constitute a majority, and their attitudes and behavior toward non-Muslims as religiously-differentiated minorities define the extent to which Muslims tolerate them, respect them as human beings, and consider them as citizens who have equal rights including political rights. This study is therefore restricted to Muslims' tolerance toward non-Muslims, to the extent to which Muslims respect and consider non-Muslims as persons who share basic human rights, and also as citizens who have equal political rights.

\section{Some Hypotheses}

Several hypotheses plausibly help explain tolerance among Muslims. They include institutional engagement, democratic values, civic engagement, political engagement, political, economic, and security conditions, religiosity, ethnicity, and education.

Institutional engagement. According to a major qualitative study by Ramage (1995), religio-political tolerance in Indonesia is shaped by the state doctrine Pancasila (Five Principles), which include Belief in One God, Just and Civilized Humanity, Unity of Indonesia, People's Sovereignty, and Social Justice. These principles guide the Constitution, originally adopted in 1945 at the time of the Independence Revolution, and are the essential ideological framework for mediating the country's extraordinarily complex 
societal pluralism. At the time of independence, and then especially importantly during the New Order era, Nahdlatul Ulama (NU), the largest Muslim organization in the country, played a crucial role in persuading Muslims to accept Pancasila, as opposed to Islamic law (syariat Islam), as the basis of the state. ${ }^{2}$ Ramage's study is restricted to the interpretation of opinions of Muslim leaders, especially from NU.

My purpose is to develop these findings more systematically and to explore variation in viewpoints at the mass level. One issue is the causal relationship between institutional engagement and religio-political tolerance. It is likely that institutional engagement is defined by religious tolerance. My main theoretical argument is that institutions matter (Hall and Taylor 1996; North and Weingast 1989). They shape individual attitudes and behavior, or at least (I claim) individual understandings and interpretations of institutions shape attitudes and behaviors, including tolerance. By institutional engagement I mean mass attitudes toward various institutions, including ideas or ideology (Hall and Taylor 1996). In this study, institution refers to Pancasila, the central motivating idea of the Indonesian Constitution. ${ }^{3} \mathrm{I}$ argue that the more positive attitudes expressed by Muslims toward Pancasila the more tolerant religio-politically they are toward non-Muslims. Theoretically and historically, Pancasila was introduced to and socialized among citizens to make them more tolerant. Were people already tolerant, there would be no point in introducing and promoting it as an ideology. The reverse causal direction, that tolerance produced Pancasila, was not a theoretical or historical possibility.

Democratic values. Political tolerance is not identical with democracy or with democratic values (Sullivan, Piereson, and Marcus 1982). For example, a polity may have free contestation in a general election but at the same time many citizens do not behave in a tolerant fashion toward a minority group. Tolerance and democratic values may be closely correlated, but they are not identical.

At the individual leval, a person may state that he or she prefers democracy or political contestation but at the same time may not be tolerant of persons who have different social identity or political views to participate in that contestation simply because of those differences in views. Another example is that, while Indonesia is a democracy, atheists are not allowed to express their lack of faith in public because Pancasila and the Constitution do not include atheists but only Believers in One God, the First Principle. 
Many studies have found that democratic values strongly predict political tolerance. The stronger the commitment to democratic values the more likely a person is to be tolerant (Gibson 1998b; Sullivan, Piereson, and Marcus 1982). Nevertheless, some research indicates that democratic values have a negative relationship with political tolerance (Duch and Gibson 1992). Yet another study found that democratic values do not have a significant relationship with political tolerance (Gibson 1998a, 1998b). In those cases, the relationship between democratic values and tolerance is institutionally and historically contextual, that is, shaped by specific characteristics of objects of tolerance in the society. Democrats in Germany are not tolerant toward Nazis whom they consider totalitarians and racists. Russians today are not tolerant toward Leninists and Stalinists because those doctrines failed in recent memory.

Taken together, these studies imply that the relationship between democratic values and tolerance has not been conclusively established. My goal is to test the contested findings in the Indonesian case.

Civic engagement. Social capital basically refers to good will, friendship, and sympathy in social interaction. Putnam characterizes social capital as mutual trust, reciprocal norms, and networks of civic engagement (Putnam 1993, 167). In my view, mutual trust, sympathy, cooperation, and reciprocal norms are fundamentally shaped by civic engagement. Being engaged in the civic community and associations helps citizens to become informed about various public issues, to learn to live in a more pluralistic community, and to see the importance of mutual cooperation. It builds mutual trust, assures personal survival, and creates access to various interest groups and to political mobilization. Civic engagement helps citizens build interpersonal trust and tolerance. In other words, the more engaged a person is in community activity the more likely he or she is to be tolerant. Some studies have verified this relationship (Cigler and Joslyn 2002; Côté and Erickson 2009; Wise and Driskell 2017).

Types of civic engagement are likely to be sensitive to religiopolitical tolerance. In Indonesia, civic engagement includes both religion based and non-religion based community activities. A study by Menchik (2016, 62-63) has found that religion based activities decrease tolerance.

Menchik's study is restricted to Muslim organizational elites. Admittedly, those elites are from the three largest and most important Muslim organizations: Nahdlatul Ulama, Muhammadiyah, and 
Persis. But my concern is whether his findings are consistent with mass attitudes. Elites frequently follow mass attitudes and behavior concerning religio-political tolerance. Mass attitudes and behavior are also therefore crucial in the study of tolerance. Elites are frequently placed in difficult positions when controversial issues such as intolerance against particular groups emerge at the mass level (Marcus et al. 1995, 207-8). Mass attitudes and behavior regarding fundamental issues such as tolerance toward minority rights are therefore crucial to help or to constrain elites in making policy decisions.

Another analysis found that religion based civic engagement does not matter for political tolerance (Menchik and Pepinsky 2018). The literature on the subject is not conclusive, however. No study has found that civic engagement is likely to increase religio-political tolerance in Indonesia. My purpose is to test whether engagement in non-religion based community activities such as labor unions, farmers' organizations, youth organizations, cultural clubs, sports clubs, local community associations, etc. increases religio-political tolerance as that type of civic engagement is more diverse in terms of social identity and therefore helps a person to learn more pluralism.

Political engagement. Political engagement is an active dimension of democratic culture (civic culture) (Almond and Verba 1963). It refers to activities such as political discussion, exposure to political news, and political attitudes such as interest in politics, political efficacy, and self identification with a political party (partyID). All of these attitudes and behaviors are psychological sources that help political participation, which will in turn be stable if accompanied by the passive dimension of democratic culture, that is political trust and tolerance. I argue that political engagement helps citizens to become more exposed to and engaged with the understanding that plurality in society is natural, and more accepting that plurality and difference are necessities for personal and collective survival. Tolerance is likely to emerge from that engagement. I hypothesize that political engagement is not negatively associated with religio-political tolerance. On the contrary, it strengthens it. Otherwise, political engagement will complicate democracy, making it unstable.

Political, economic, and security conditions. Democracy emerged in relatively stable and economically developed societies (Lipset 1959). It is highly unlikely to emerge in insecure societies because of wars, severe conflicts, and economic shortages (Norris and Inglehart 2011). In such 
societies trust and tolerance will be hard to come by. At the individual level, persons who evaluate economic, political, and security conditions as poor are likely to be intolerant, and vice versa.

Religion and Ethnicity. In a religiously or ethnically divided society bulding tolerance among fellow citizens is a difficult task as "ethnic or religious identity is incorporated so early and so deeply into one's personality, conflict among ethnic and religious subcultures is specifically fraught with danger.... Because conflicts among ethnic and religious subcultures are so easily seen as threats to one's most fundamental self, opponents are readily transformed into a malign and inhuman 'they' whose menace stimulates and justifies the violence and savagery that have been the common response of in-group to out-group among all mankind" (Dahl 1971, 108).

At the individual level, a person belonging to a given religion is likely to be intolerant toward those who belong to other religions (Beatty and Walter 1984). Muslims may also be intolerant relative to non-Muslims (Milligan, Andersen, and Brym 2014). Religion may also be defined as individual religiosity or piety, i.e. the intensity or degree to which a person is religious. A more religious person is more likely to be intolerant (Beatty and Walter 1984). Religious Muslims relative to irreligious Muslims are found to be intolerant (Milligan, Andersen, and Brym 2014). Studies of Indonesian Muslim elites and masses in Indonesia found similar relationships (Menchik 2016; Mujani 2003, 2007). Nevertheless, one study does find that religion does not matter for political tolerance vis a-vis psychological and political determinants of political tolerance (Eisenstein 2006). My research tests these contested findings.

Like religion, as Dahl argues, ethnicity in a multi-ethnic society may threaten tolerance. Menchik found that ethnicity is significantly related to tolerance among Muslim elites: Javanese are more tolerant toward non-Muslims than other ethnic groups (Menchik 2016). This study tests the extent to which ethnicity is associated with religio-political tolerance at the mass level.

Education. Another demographic factor believed crucial regarding political tolerance is education. Many studies have found that education predicts tolerance. The more educated a person the more likely he or she is to be tolerant (Marcus et al. 1995; Sullivan, Piereson, and Marcus 1982). Education is believed to expose citizens to modern values such as freedom and pluralism. It is also believed to help concretize abstract concepts and values. 


\section{Measurement}

This research is designed to test hypotheses and present findings. Verification depends absolutely on how the relevant concepts and variables are measured. That is, how I measure religio-political tolerance, civic and political engagement, democratic values, institutional engagement, political economy and security conditions, religion and religiosity, and other basic demographic variables.

Measurement of religio-political tolerance is not "a controlled content measure" of political tolerance in general as suggested by Sullivan, Piereson, and Marcus (1982). This study is designed not to explain political tolerance in general but to explain specifically religiopolitical tolerance among Muslims. It does not observe dynamics or trends of political tolerance. More particularly in the context of the Muslim world, it is crucial to examine religio-political tolerance that affects democracy and democratic consolidation (Huntington 1997). In the context of Indonesia, tolerance is frequently associated with religious tolerance. For detailed measures and wordings of religiopolitical tolerance, see Appendix 1.

\section{Methodology and Data}

This study relies on nation-wide public opinion surveys. The population is voting age Muslims, about $87 \%$ of the national population. For detailed information on methodology and data see Appendix 2.

\section{Findings}

Table 1 shows how tolerant or intolerant religio-politically Indonesians are. On a three point scale of religio-political tolerance, Indonesian Muslims are in general intolerant (mean score $=1.890$ on a 1-3 scale). ${ }^{4}$ This finding verifies previous studies (Mietzner and Muhtadi 2018). These studies did not, however, analytically explain intolerance, but rather interpreted the possible causes of the phenomenon. They did not review the various factors that might potentially explain it. My study tests explanations of religio-political tolerance in which various factors are believed crucial: institutional engagement, democratic values, civic engagement, political engagement, political, economic, and security assessments, religiosity, ethnicity, and some other basic demographic variables. Table 1 displays descriptive statistics of the explanatory variables. 
Table 1. Descriptive Statistics

\begin{tabular}{|l|c|c|c|c|c|}
\hline \multicolumn{1}{|c|}{ Variable } & $\mathrm{N}$ & $\mathrm{Min}$ & $\mathrm{Max}$ & Mean & $\begin{array}{c}\text { Std. } \\
\text { Deviation }\end{array}$ \\
\hline Index of religious tolerance & 1865 & 1.00 & 3.00 & 2.033 & .850 \\
\hline $\begin{array}{l}\text { Index of religion based } \\
\text { political tolerance }\end{array}$ & 1865 & 1.00 & 3.00 & 1.746 & .882 \\
\hline $\begin{array}{l}\text { Index of religio-political } \\
\text { tolerance }\end{array}$ & 1865 & 1.00 & 3.00 & 1.890 & .750 \\
\hline Gender: Male (1) & 1865 & .00 & 1.00 & .502 & .500 \\
\hline $\begin{array}{l}\text { Rural urban cleavage: Rural } \\
\text { (1) }\end{array}$ & 1865 & .00 & 1.00 & .482 & .500 \\
\hline Age & 1865 & 17.00 & 89.00 & 43.654 & 13.900 \\
\hline Education & 1825 & 1.00 & 10.00 & 5.024 & 2.406 \\
\hline Ethnicity: Javanese (1) & 1865 & .00 & 1.00 & .466 & .499 \\
\hline Index of Muslim religiosity & 1841 & 1.00 & 5.00 & 3.768 & .653 \\
\hline $\begin{array}{l}\text { Index of all social } \\
\text { organization membership }\end{array}$ & 1865 & .00 & .58 & .089 & .101 \\
\hline $\begin{array}{l}\text { Index of Islamic } \\
\text { organization membership }\end{array}$ & 1865 & .00 & .60 & .108 & .140 \\
\hline $\begin{array}{l}\text { Index of non-religious } \\
\text { (Islamic) organization } \\
\text { membership }\end{array}$ & 1865 & .00 & .71 & .076 & .114 \\
\hline Political interest & 1865 & 1.00 & 5.00 & 2.463 & 1.268 \\
\hline Political discussion & 1840 & 1.00 & 5.00 & 2.257 & 1.194 \\
\hline Exposure to political news & 1826 & 1.00 & 5.00 & 2.123 & .780 \\
\hline $\begin{array}{l}\text { Index of political } \\
\text { engagement (political } \\
\text { interest + political } \\
\text { discussion + exposure to } \\
\text { political news) }\end{array}$ & 1801 & 1.00 & 4.75 & 2.291 & .867 \\
\hline $\begin{array}{l}\text { Index of institutional } \\
\text { engagement }\end{array}$ & 1865 & 1.90 & 5.00 & 4.028 & .564 \\
\hline Index of democratic values & 1865 & 1.00 & 5.00 & 4.373 & .519 \\
\hline $\begin{array}{l}\text { Index of politcal, } \\
\text { economic, and security } \\
\text { conditions. }\end{array}$ & 1865 & 1.00 & 5.00 & 3.289 & .579 \\
\hline Voter turnout: vote (1) & 1865 & .00 & 1.00 & .845 & .362 \\
\hline
\end{tabular}


Institutional engagement, i.e. attitudes toward the core of the Indonesian Constitution or Pancasila, is very high (mean score $=4.028$ on a $1-5$ point scale $)^{5}$ (Table 1 ). The overwhelming majority disagree or strongly disagree that the Five Principles should be amended. Indonesians agree that Belief in One God, Just and Civilized Humanity, the Unity of Indonesia, People's Sovereignty, and Social Justice should remain in the Constitution.

The crucial issue for tolerance is the First Principle, i.e. Belief in One God. If this principle is retained in the Constitution in its current form, there will be no room for non-believers. In addition there is no room for any religion except those officially accepted by the state. Judaism and many local religions for example are not officially accepted. It is a key institutional legitimating benchmark for state intervention in matters of religious freedom, seminal in determining the mainstream conception of religious freedom. In Indonesia, on this topic, the elites tend to follow the mainstream.

The First Principle is the main source of discrimination against minorities, and the blasphemy law relies on it. However, on the issue of religio-political tolerance, I expect that institutional engagement will strengthen Muslim religio-political tolerance toward citizens adhering to other religions as long as they are officially accepted by the state, but not toward unbelievers or unofficial religions. ${ }^{6}$

In addition, Indonesian Muslims in general are committed to democratic values $($ mean $=4.373$ on a $1-5$ point scale $) .{ }^{7}$ They state that freedom of expression, religious freedom, freedom to understand or interpret religious tenets, freedom of assembly, equality before the law, criticizing government, direct elections for heads of government, and a majority vote for heads of government, are crucial.

The third potentially explanatory variable for religio-political tolerance is civic engagement. In this study, civic engagement is citizens' membership in various social organizations or civic associations such as religious organizations, unions, farmers associations, youth associations, sports and cultural clubs, etc. Most Muslims are not socially engaged as measured by their membership in these organizations (mean $=.089$ on a $0-1$ point scale).$^{8}$

Political engagement is also believed to enjoy a positive relationship with religio-political tolerance. It includes interest in politics, exposure to political news, political discussion, and party identification. As 
previously discussed, political engagement is the active side of the democratic culture. If the relationship with the passive element of the culture, i.e. tolerance, is congruent, this congruency will be crucial to strengthening the democratic system. Political engagement has the potential to strengthen tolerance as it exposes citizens to a more complex and diverse society. This exposure in turn helps citizens to learn to accept the pluralistic nature of society.

Table 1 shows how engaged people are with politics. Most people are not in fact politically engaged (mean $=2.1$ on a $1-5$ point scale). ${ }^{9}$ They generally do not discuss politics $($ mean $=2.257)$, are not interested in politics (mean = 2.465 ), and are not exposed to political news (mean $=2.123$ ).

Close to political engagement is political participation. The former is attitudinal, while the later is behavioral. If a democracy is to become stable and strong, political participation and political tolerance should be congruent. As previously stated, political participation does not mean democratic development without tolerance. The question is the extent to which political participation relates positively or negatively to religio-political tolerance. If the relationship is negative, participation will threaten democratic stability and consolidation.

Voter turnout in a democratic election is a basic measure of political participation. Table 1 shows that most people reported that they had in fact voted in the last parliamentary election (mean $=0.845$, on a $0-1$ point scale).$^{10}$

As previously discussed, assessment of political economy, law and order, and security conditions is likely to explain religio-political tolerance. A person who assesses these conditions more positively will feel secure. He or she will in turn not see other people of various backgrounds as threats, and will therefore be more open, more welcoming to them. My survey indicates that most Indonesian Muslims assessed the conditions positively (mean $=3.289) .{ }^{11}$ Economic and political conditions were good or moderate, while law and order and national security were good.

Previous studies have found that Muslim religiosity significantly affects religio-political tolerance in a negative way (Menchik 2016). In addition, most Indonesian Muslims are pious (Pepinsky, Liddle, and Mujani 2018). This finding is confirmed: most Indonesian Muslims are pious (mean $=3.768$ on a $1-5$ point scale) (Table 1$)$. They regularly conduct mandatory rituals such as the five daily prayers and Ramadhan fasting. In addition, a significant number of Muslims conduct suggested 
rituals such as collective prayer (salat berjamaah), personal prayer (salat sunnab), reciting the Qur'an, religious group studies (pengajian, or majelis taklim), and collective sermons (tablilan, yasinan, or selametan). Demographic variables vary greatly: Education, rural-urban cleavage, ethnicity, age, and gender (Table 1). They are also expected to affect religio-political tolerance.

Although all items of religio-political tolerance are highly correlated, factor analysis indicates that religious tolerance and religion based political tolerance are distinct. For further analysis, tolerance has been constructed into three types: religio-political tolerance, religious tolerance and religion based political tolerance. They are treated separately in the analysis. ${ }^{12}$

Table 2 shows correlations between the relevant variables and the three types of tolerance. These variables, i.e. institutional engagement, democratic values, a particular type of civic engagement, political engagement, political economy, law and order and security conditions, religiosity, ethnicity, ruralurban cleavage, education, and age, have significant correlations with one, two, or all three types of tolerance (religio-political tolerance, religious tolerance and religion based political tolerance).

Civic engagement correlates significantly with tolerance when it is defined as non-religious (Islamic) organizations. Islamic organization membership, which is greater because of the size of organizations like Nahdlatul Ulama, Muhammadiyah, Persis, etc. does not correlate with tolerance. Some studies which conclude that NU at the elite level is a positive source for tolerance are not consistent with the finding in this study about those organizations' masses. ${ }^{13}$

In addition, the proposition previously discussed that Islam is negative for tolerance is verified when Islam is defined as Muslim religiosity. The more religious a Muslim, the more likely to be intolerant (Table 2).

Gender does not correlate significantly with any of the three types of tolerance. Voting as a measure of political participation also is not related, which indicates that political participation does not threaten tolerance.

Age correlates significantly only with religious tolerance. Older citizens are more intolerant. Rural background correlates significantly with religious tolerance. Rural people tend to be religiously intolerant. Education, however, significantly correlates positively with religious tolerance, but it does not for religion based political tolerance (Table 2). 
Table 2. Correlates of Religio-Political Tolerance (Pearson's Correlation)

\begin{tabular}{|l|c|c|c|}
\hline & $\begin{array}{c}\text { Religious } \\
\text { tolerance }\end{array}$ & $\begin{array}{c}\text { Religion based } \\
\text { poltitical } \\
\text { tolerance }\end{array}$ & $\begin{array}{c}\text { Overall } \\
\text { religio-political } \\
\text { tolerance }\end{array}$ \\
\hline Gender: Male & .036 & .041 & .045 \\
\hline Rural-urban cleavage: Rural & $-.086^{* * *}$ & -.018 & $-.059^{*}$ \\
\hline Age & $-.078^{* * *}$ & .010 & -.038 \\
\hline Education & $.124^{* * *}$ & .021 & $.083^{* * *}$ \\
\hline Ethnicity: Javanese & $.276^{* * *}$ & $.240^{* * *}$ & $.298^{* * *}$ \\
\hline Religiosity & $-.068^{* *}$ & $-.134^{* * *}$ & $-.118^{* * *}$ \\
\hline Membership in all social organization & .037 & .024 & .035 \\
\hline Membership in Islamic organization & -.033 & -.038 & -.041 \\
\hline $\begin{array}{l}\text { Membership in non-religious (Islamic) } \\
\text { organizations }\end{array}$ & $.086^{* * *}$ & $.069^{* *}$ & $.089^{* * *}$ \\
\hline Political engagement & $.091^{* * *}$ & $.048^{*}$ & $.080^{* * *}$ \\
\hline Institutional engagement & $.164^{* * *}$ & $.095^{* * *}$ & $.149^{* * *}$ \\
\hline Democratic values & $.115^{* * *}$ & $.047^{*}$ & $.093^{* * *}$ \\
\hline $\begin{array}{l}\text { Political, economic, law and order, and } \\
\text { security conditions }\end{array}$ & $.067^{* *}$ & $.144^{* * *}$ & $.123^{* * *}$ \\
\hline Voting & -.041 & .010 & -.017 \\
\hline
\end{tabular}

Multivariate analysis helps demonstrate the extent to which correlations are consistent. The three dependent variables were constructed as religious tolerance (Model 1), religion based political tolerance (Model 2), and overall religio-political tolerance (Model 3).

In Model 1 (religious tolerance), ethnicity, relative to other predictors, is the strongest predictor of religious tolerance (Table 3). ${ }^{14}$ Being a Javanese Muslim relative to non-Javanese Muslims has a positive and significant relationship with religious tolerance. In addition, being Javanese has a significant and positive relationship with political and overall religio-political tolerance as well (Model 2 and Model 3). Javanese are more tolerant not only in daily religious life such as listening to sermons and building prayer places in their neighborhoods but also in the political realm, concerning strategic public offices. Being a Javanese Muslim is positive for non-Muslims to be public officials.

The second most consistent predictor of religious, political, and overall religio-political tolerance is Muslim religiosity (Table 3). This impact 
is contrary to being ethnically Javanese. The more religious or pious a Muslim, the more intolerant. Muslim religiosity decreases tolerance while being Javanese increases tolerance. This finding verifies previous studies (Menchik 2016; Mietzner, Muhtadi, and Halida 2018).

The third best predictor of religio-political tolerance is perceptions of the political economy, law and order, and security conditions. The more positively a Muslim perceives political, economic, law and order, and national security conditions the more tolerant he or she is toward non-Muslims, and vice versa. This tolerance is both in daily religious life and in political life. This finding verifies the hypothesis previously discussed that assessment of political economy, law and order, and national security conditions explains tolerance (Table 3).

Previous studies ignored this important effect of political, economic, and security conditions on religio-political tolerance. Accordingly, this finding is an original contribution to the study of religio-political tolerance in Indonesia. A person who feels secure economically and politically is likely to be more open to others who differ in social identity backgrounds and in socio-political interests and ideas. People do not see other people of different identity backgrounds and interests as threats because they already feel secure. On the other hand, those who feel insecure are likely to be suspicious of those whose backgrounds and interests differ. The others are likely perceived as threats.

The fourth best predictor of tolerance is institutional engagement or attitudes toward Pancasila, the core guiding idea of the Constitution (Table 3). As expected, this factor increases overall religio-political tolerance. The more engaged a Muslim is with these core ideas, the more likely he or she will be tolerant toward non-Muslims. This institutional engagement helps increase daily religious tolerance among Muslims. In addition, it increases religion based political tolerance (Model 2). Institutional engagement increases Indonesian Muslim tolerance in daily religious life and in the political realm. A Muslim who is institutionally engaged tolerates a non-Muslim holding strategic public offices such as president, governor, or mayor. This pattern is also an original finding in the study of religio-political tolerance in the Indonesian case at the mass level, and it verifies a previous elite study (Ramage 1995).

Democratic values are believed to have a positive relationship with tolerance (Sullivan, Piereson, and Marcus 1982). This hypothesis is partially verified (Model 1, Table 3). Commitment to democratic values increases religious tolerance but not religion based political tolerance. In other words, in the case of Indonesia, democratic values do not increase religio-political tolerance. 
In addition, a hypothesis that political engagement explains tolerance is partially verified (Model 2, Table 3). That is, it explains religion based political tolerance but not religious tolerance. A Muslim who is interested in politics, exposed to political news via various mass media, and frequently discusses politics is more politically tolerant. The idea that political engagement helps citizens learn the plural nature of public life and the need for pluralism is persuasive. In other words, following political news and engaging in political discussion are likely to increase people's interest in politics and increase their understanding of the complex and diverse nature of politics in terms of others' backgrounds and interests.

Table 3. Multivariate Analysis of Muslim Tolerance

(Regression coefficients and standard errors)

\begin{tabular}{|c|c|c|c|c|c|c|}
\hline & \multicolumn{2}{|c|}{ Model 1} & \multicolumn{2}{|c|}{ Model 2} & \multicolumn{2}{|c|}{ Model 3} \\
\hline Parameter & B & SE & B & SE & B & SE \\
\hline (Constant) & $1.001^{* * *}$ & .264 & $1.022^{* * *}$ & .259 & $.969^{* * *}$ & .222 \\
\hline Age & -.003 & .002 & - & - & - & - \\
\hline $\begin{array}{l}\text { Rural-uban } \\
\text { cleavage: Rural }\end{array}$ & $-.100^{*}$ & .041 & - & - & $-.072^{*}$ & .035 \\
\hline Education & $.025^{* *}$ & .009 & - & - & $.017^{*}$ & .008 \\
\hline $\begin{array}{l}\text { Ethnicity: } \\
\text { Javanese }\end{array}$ & $.417^{* * *}$ & .040 & $.368^{* * *}$ & .041 & $.387^{* * *}$ & .035 \\
\hline Muslim religiosity & $-.105^{* * *}$ & .032 & $-.198^{* * *}$ & .031 & $-.164^{* * *}$ & .026 \\
\hline $\begin{array}{l}\text { Non-religious } \\
\text { social organization } \\
\text { membership }\end{array}$ & .147 & .175 & .222 & .182 & .181 & .152 \\
\hline $\begin{array}{l}\text { Political } \\
\text { engagement }\end{array}$ & .029 & .025 & $.052^{*}$ & .024 & .042 & .021 \\
\hline $\begin{array}{l}\text { Institutional } \\
\text { engagement }\end{array}$ & $.118^{* *}$ & .037 & $.077^{*}$ & .038 & $.091^{* *}$ & .032 \\
\hline Democratic values & $.089^{*}$ & .040 & .057 & .041 & $.077^{*}$ & .034 \\
\hline $\begin{array}{l}\text { Political, economic, } \\
\text { and security conditions }\end{array}$ & $.103^{* *}$ & .034 & $.186^{* * *}$ & .035 & $.150^{* * *}$ & .030 \\
\hline R-Square & .115 & & 098 & & .135 & \\
\hline $\mathrm{N}$ & 1745 & & 1782 & & 1745 & \\
\hline
\end{tabular}

***P, $\mathrm{P}^{* *}$, or $\mathrm{P}^{*}$ is statistically significant at $.001, .01$, and .05 or better respectively.

"_" indicates that the correlation in bivariate statistics is not significant, and is excluded in the models. 
As previously discussed, civic engagement helps citizens learn the importance of cooperation or mutual help for their existential survival in addition to resolving problems of collective action in public life. Civic engagement is also believed to help citizens respect fellow citizens and to help them learn to accept the fact that society is pluralistic. Tolerance among fellow citizens is therefore a necessity for their survival.

However, this study found that civic engagement is not related to tolerance after considering other relevant factors (Table 3). Membership in various non-religious social organizations as a measure of civic engagement does not have a direct impact on religious, political, or overall religiopolitical tolerance. People who are engaged in diverse civic activities are small in number. A significant number of those are engaged in religious organizations which are more homogeneous in social identity. They do not have the opportunity to learn pluralism from their engagement, and at the same time their engagement does not significantly strengthen tolerance after taking into account religiosity, ethnicity, economic, political, and security conditions, and institutional engagement.

Many studies have found that education is crucial in explaining tolerance (Sullivan, Piereson, and Marcus 1982). Education, it is argued, helps citizens bring abstract ideas of pluralism and democratic values down to earth. This study partially verifies this conclusion (Model 1, Table 3). Education increases religious tolerance among Muslims controlling for relevant variables. However, it does not affect religion based political tolerance (Model 2, Table 3). Tolerance in daily life and in the political realm are distinct, and education is not powerful enough to increase religion based political tolerance as this tolerance is likely to be a more sensitive issue than tolerance in daily life (religious tolerance).

In other words, improved education level in Indonesia does not increase religio-political tolerance. This finding verifies a commonlyheld view in Indonesia that the educated are frequently responsible for intolerant opinions and protests. In addition, a recent study found that a majority of public school teachers are intolerant (PPIM UIN Jakarta 2016). Education cannot therefore be expected to strengthen religiopolitical tolerance relative to institutional engagement and economic, political, and security conditions.

Rural-urban cleavage, another demographic background factor, partially relates to tolerance. Being an urbanite, relative to a rural 
person, increases tolerance. However, like education, it directly explains religious tolerance, but does not relate to religion based political tolerance (Table 3).

In the bivariate statistics, age matters for religious tolerance (Table 2). The younger a Muslim, the more religiously tolerant. However, this significance disappears when other relevant independent variables are considered. In other words, age does not directly matter for tolerance.

\section{Discussion}

This study attempts to explain religious, religion based political, and overall religio-political tolerance among Indonesian Muslims. It is a fact that democracy is still a rare phenomenon in Muslim majority countries. Moreover, several studies claim that democracy is rare in those countries due to the absence of tolerance (Huntington 1997). In such a situation, democracy can not emerge. In addition, once democracy is introduced in these countries, it is frequently unstable not to mention unconsolidated. As previously discussed, Dahl argues that electoral democracy or political participation does not automatically produce democracy, especially in conditions of sub-cultural pluralism. A democracy without tolerance is weak and finally fails.

Indonesia is one of a small number of democracies in the Muslim world. Tolerance in Muslim democracies is still understudied, and this research has been designed as a contribution to the rare scholarship on this issue. Indonesian democracy has been assessed to have regressed in the last 7 years or so due to the weakness of its civil liberties, especially concerning religious tolerance (Freedom House 2018). This study attempts more systematically to discover how tolerant or intolerant Indonesian Muslims are, and to explain that variation. It focuses on the attitudes of the Muslim majority (about 87\%) toward minorities, i.e. non-Muslims.

Religio-political tolerance in Indonesia is still an understudied subject. There is some literature on the subject but it is short on explanation. Potential explanatory factors are ignored: economic, political, and security conditions, institutional engagement, democratic values, political engagement, and civic engagement. The purpose of this essay is to reveal that these latter factors significantly explain the phenononeon in the Indonesian case.

Assessment of political, economic, and security conditions significantly and consistently explains tolerance, not only religious but 
also religion based political tolerance. I argue that a theory which states that existential security is crucial to democracy (Norris and Inglehart 2011) is relevant to explaining tolerance. Tolerance is an aspect of democratic culture more crucial, relative to participant culture or political engagement, to making democracy work. Existential security, measured by assessment of political, economic, and security conditions, explains tolerance, which is in turn the likely intervening variable to explain democratic stability or development.

The hypothesis that democratic values strongly predict tolerance is only partially verified, as democratic values do not help to improve tolerance in the political realm. A vast majority claim that they are committed to democratic values, but their democratic values do not significantly improve religion based political tolerance. We need further research to determine what Indonesian Muslims mean by democratic values or by democracy itelf. In particular, it is important to know whether democracy is mostly understood in terms of liberal procedures or socio-economic equality. The former is obviously more relevant to the issue of tolerance.

An elite based qualitiative study which found that Pancasila, the core principles of the Constitution, is crucial to building tolerance in Indonesia, as previously discussed, is verified in this study. Strong support for Pancasila comes not only from the elites but is also massbased. This support explains significantly and positively all types of tolerance. However, tolerance here is restricted to Muslim tolerance toward those non-Muslims who are officially accepted by the state. Institutional engagement predicts this specific tolerance rather than tolerance in general or any least-liked group in society. This focus on Muslim tolerance toward non-Muslims is my specific contribution to current discussions not only among scholars but also among members of the public who are more concerned with religio-political tolerance.

Institutional engagement, i.e. support for Pancasila, as expected, strengthens religio-political tolerance. In elite public discussion, the importance of Pancasila for religio-political tolerance at the mass level has been ignored since the fall of the New Order, since the term was identical with the regime that had been rejected by most people.

Unlike institutional engagement, civic engagement does not have a direct impact on tolerance. In this study, civic engagement is restricted to one aspect, i.e., networks of civic engagement or membership in civic associations. Membership in any social organization or group does not in fact 
automatically help people learn the importance of mutual understanding to make them tolerant. Social trust, another aspect of civic engagement or social capital, was not observed in this study. It is probably more crucial to explaining tolerance. Future studies should address this issue.

In addition, political engagement is found to be insignificant in explaining overall tolerance. This finding does at the very least indicate that political engagement does not produce intolerance. In addition, in this study, political engagement is restricted to the active dimension of democratic culture. The passive dimension, i.e. institutional trust, is probably more crucial for tolerance. Both, social and political trust, should be taken into account in explaining tolerance in future research.

Muslim religiosity significantly and consistently explains intolerance. The more religious a Muslim, the more he or she tends to be intolerant toward non-Muslims, both in the religious and political realms. This finding verifies previous studies. It also raises concern about tolerance in the future as Muslims in Indonesia and world-wide are growing more pious relative to non-Muslims. If Muslim religiosity negatively affects tolerance, it will affect democracy negatively as well, since tolerance is crucial to democratic development.

Javanese ethnic background, on the contrary, significantly and consistently strengthens tolerance. This finding is positive for Indonesian democracy since Javanese constitute by far the largest ethnic group. Why are Javanese more tolerant?

We need further study to answer this question. Geertz (1968) suggests that Javanese Muslims are different from Middle Eastern Muslims in their religious attitudes and behavior. Javanese Muslims are syncretic relative to Muslims in the Middle East or more specifically in Morocco (Geertz 1968). This makes them more inclusive or more open to other cultures and religions, more relaxed in their religious behavior.

The explanation of why Javanese are more open and inclusive can probably be found in their culture and traditions. They have a long history, including centuries of kingship, which has patterned their attitudes and behavior. Over those centuries, they were exposed to multiple religions, including animism, Hinduism, Buddhism, Islam, and Christianity. Today's Javanese culture absorbed many elements of this complex cultural experience without losing its unique and coherent identity. This fact shapes Javanese attitudes and behavior today toward other ethnic and religious identities. 
In "The Idea of Power in Javanese Culture," Anderson labels the Javanese a unique culture (Anderson 1972). Although his purpose was to offer a cultural explanation for the authoritarianism of Indonesian politics at the time, his point that Javanese culture remains a coherent whole after absorbing many cultural imports sheds light on why the Javanese are more tolerant today.

Most other ethnic groups, numbering in the hundreds, are small in size. Many do not have a history of indigenous tradition-building comparable to the Javanese. As they encountered other traditions and religions, they tended to convert to them. When Islam came to Indonesia, it tended to replace or subordinate previous group identities. In West Java, Sumatra, and Sulawesi, for example, Islam often became the new predominant identity. The ethnic identities of Sundanese in West Java, Acehnese in Aceh, Minangkabau in West Sumatra, Malay in Riau, Buginese and Makassarese in Sulawesi, all tended to be incorporated into or at least subordinated to Islam.

Once they became Muslims, members of these various groups learned how to follow Islamic traditions and interpretations of the relationship between Muslims and other religious identities. According to Bernard Lewis, a prominent historian of Islam, scripturally and historically, Islam discriminated against females, slaves, and particularly non-Muslims. Lewis cautions, however, that intolerance in any specific Muslim society must be understood in its own local socio-political context (Lewis 1998).

\section{Conclusions}

Indonesia is the largest democracy in the Muslim world, third in the entire democratic world after India and the United States. Unfortunately, Indonesian democracy shows signs of deconsolidation. Its civil liberties, especially religious freedom or religio-political tolerance, have been declining in the last seven years or so. This study was designed to discover how tolerant or intolerant are Indonesian Muslims as a majority toward non-Muslim minorities, and to explain that finding.

I found that Indonesian Muslims, $87 \%$ of the national population, are religio-politically intolerant. They are intolerant especially toward non-Muslim public officials. Potential explanatory factors that have been ignored by previous studies include economic, political, and 
security conditions, institutional engagement, and democratic values. This study has demonstrated that these factors are crucial to decreasing religio-political intolerance. This finding is my main contribution to scholarship on the subject in Indonesia and beyond.

In addition, this study has demonstrated that civic and political engagement were found insignificant in predicting religio-political tolerance. Membership in any civic association and a high level of political interest do not automatically increase tolerance. The insignificance of these two forms of engagement is likely due to the absence of observation of social and political trust in this model, a key issue that should be adddressed in future research.

Muslim religiosity, as found in previous studies, decreases religiopolitical tolerance. The negative impact of religiosity will be more significant if Javanese culture, political, economic, and security conditions, institutional engagement, and commitment to democratic values among the population weaken. The prospects for Indonesian tolerance and democracy are partly defined by the interaction between religion and religiosity on the one hand, and Javanese culture, political, economic, and security conditions, institutional engagement, and commitment to democratic values on the other. If the latter prevail over the former, religio-political tolerance will increase, which will in turn strengthen the country's democracy. 
Appendix 1: Measures and Wordings of Tolerance

1. Would you mind if non-Muslims conduct collective rituals (acara kebaktian atau ibadah) here in your neighborhood? 1. Yes 2. No 3. Depends

2. Would you mind if non-Muslims build a prayer house (rumah ibadah) here in your neighborhood? 1 . Yes 2. No 3. Depends

3. Would you mind if a non-Muslim becomes mayor of this city or municipality? 1. Yes 2. No 3. Depends

4. Would you mind if a non-Muslim becomes governor of this province? 1. Yes 2. No 3. Depends

5. Would you mind if a non-Muslim becomes vice-president of this country? 1. Yes 2. No 3. Depends

6. Would you mind if a non-Muslim becomes president of this country? 1. Yes 2. No 3. Depends

\section{Appendix 2: Methodology and Data}

This study is based on two nation-wide public opinion surveys conducted in September and December 2018 by the Saiful Mujani Research and Consulting (SMRC) survey firm. The sample size was 1200 for each survey, and the response rates were $88 \%$ and $85.7 \%$. The analysis is restricted to Muslims relevant for this study.

The sampling technique is multi-stage random sampling. The national population of voting age was stratified according to the 34 Indonesian provinces, in addition to the proportions of rural-urban cleavage and gender. Samples were drawn proportionately to the population in each province. Primary sampling units (village or urban ward, desa or kelurahan in Indonesian) were then randomly selected. In each selected village or urban ward 5 neighborhood associations (Rukun Tetangga, RT) were selected randomly from the list available at the local administrative office. In each RT two houses were randomly selected; in each selected house, one male or female household member of voting age was randomly selected to be the survey respondent by using the Kish Grid to be the survey respondent. If in the first house the respondent was male, in the next she was female.

Interviews were conducted face to face with the selected respondents by a numerator. Each numerator was responsible for 10 respondents. 
Quality control was exercised by spot checks and by calling selected respondents. Spot checks were conducted of $20 \%$ of randomly selected respondents, and $60 \%$ of randomly selected respondents were telephoned, ensuring that the interviews were properly conducted. Detailed description of the representativeness of the samples relative to the population is available from the author.

Appendix 3: Measures, Wordings, and Index Constructions of the Variables

\begin{tabular}{|c|c|c|}
\hline No & Variable Label & Wordings, Values / Code/index \\
\hline 1 & Gender (male) & $1=$ male, $0=$ female \\
\hline 2 & Rural-urban (rural) & $1=$ rural, $0=$ urban \\
\hline 3 & Age & Age in years \\
\hline 4 & Education & $\begin{array}{l}\text { Final education level on a scale of 1-10: } 1=\text { no } \\
\text { school, } 10=\text { university bachelor's degree or } \\
\text { higher }\end{array}$ \\
\hline 5 & Ethnicity (Javanese) & $1=$ Javanese, $0=$ other \\
\hline 6 & Muslim religiosity & $\begin{array}{l}\text { How frequently do you conduct the following } \\
\text { activity? Mandatory prayer, Ramadhan } \\
\text { fasting, collective prayer, suggested personal } \\
\text { prayer, recite Qur'an, participate in religious } \\
\text { studies group (pengajian), listen to sermons } \\
\text { (tahlilan or selamatan). Very often }=4 \text {, quite } \\
\text { often }=3 \text {, rarely }=2 \text {, never }=1 \text {. } \\
\text { Muslim religiosity is a } 4 \text {-point additive scale } \\
\text { of the seven items. }\end{array}$ \\
\hline 7 & $\begin{array}{l}\text { Muslim religious tolerance } \\
\text { index } \\
(1-3)(2 \text { item index })\end{array}$ & $\begin{array}{l}\text { Index combining } 2 \text { tolerance items: Non- } \\
\text { Muslims conduct events/services and non- } \\
\text { Muslims build places of worship. } \\
\text { Each item is measured on a scale of } 1-3 \\
\text { points ( } 1=\text { object, } 2=\text { depends/no answer, } \\
3=\text { no objection. These two items are averaged } \\
\text { to form an index on a scale of } 1-3 \text { ( } 1=\text { very } \\
\text { intolerant, } 3=\text { very tolerant). }\end{array}$ \\
\hline 8 & $\begin{array}{l}\text { Religion based political } \\
\text { tolerance index } \\
(1-3)(4 \text { item index })\end{array}$ & $\begin{array}{l}\text { Index combining } 4 \text { tolerance items: } 1 \text { ) Non- } \\
\text { Muslim may become district head/mayor, } 2 \text { ) } \\
\text { Non-Muslim may become governor, } 3 \text { ) Non- } \\
\text { Muslim may become vice-president, } 4 \text { ) Non- } \\
\text { Muslim may become president. } \\
\text { Each item is measured on a scale of } 1-3 \text { points } \\
(1=\text { object, } 2=\text { depends/no answer, } 3=\text { no }\end{array}$ \\
\hline
\end{tabular}




\begin{tabular}{|c|c|c|}
\hline & & $\begin{array}{l}\text { objection). The four items are averaged to } \\
\text { form an index with a scale of } 1-3(1=\text { very } \\
\text { intolerant, } 3=\text { very tolerant). }\end{array}$ \\
\hline 9 & $\begin{array}{l}\text { Religio-political tolerance } \\
\text { index }\end{array}$ & $\begin{array}{l}\text { Index combining } 2 \text { tolerance indexes: } \\
\text { Muslim religious tolerance and religion } \\
\text { based political tolerance. } \\
\text { Each variable is scaled } 1-3 \text {. The two items are } \\
\text { averaged to form an index with a scale of } 1-3 \\
\text { (1=very intolerant, } 3=\text { very tolerant). }\end{array}$ \\
\hline 10 & $\begin{array}{l}\text { Importance of democratic } \\
\text { values } \\
(1-5)(8 \text { items index })\end{array}$ & $\begin{array}{l}\text { How important are the following values to } \\
\text { you? Very important, important enough, } \\
\text { less important, not important at all? } \\
\text { 1) Freedom of opinion, 2) Freedom of } \\
\text { worship, whatever religion or belief system } \\
\text { is adhered to, 3) Freedom to understand } \\
\text { or interpret a religion (differs from } \\
\text { freedom to choose a religion. Interpreting } \\
\text { a religion is not free if it is dominated by } \\
\text { an authoritative state or official position), } \\
4 \text { ) Freedom of association, } 5 \text { ) Equality } \\
\text { of rights and obligations for all citizens } \\
\text { regardless of religion, ethnicity, race, } \\
\text { and region, } 6 \text { ) Freedom to criticize the } \\
\text { government, } 7 \text { ) Choose directly the head } \\
\text { of government, } 8 \text { ) State leader must win } \\
\text { the most votes (majority) in elections } \\
\text { Each item is measured on a scale of } 1-5 \text { points: } \\
\text { (1=not important at all, } 2=\text { less important, } \\
3=\text { don't know/no answer, } 4=\text { important } \\
\text { enough, } 5=\text { very important. } \\
\text { All items are added to form an index on a scale } \\
\text { of } 1-5:(1=\text { very strongly against democratic } \\
\text { values, } 5=\text { very pro democratic values). }\end{array}$ \\
\hline \multirow[t]{3}{*}{11} & \multirow{3}{*}{$\begin{array}{l}\text { Institutional engagement: } \\
\text { attitude toward Pancasila } \\
(1-5)(10 \text { item index })\end{array}$} & Ten items: \\
\hline & & $\begin{array}{l}\text { 1. Opinion about Pancasila and the } 1945 \\
\text { Constitution: } 1=\text { most of it has to be } \\
\text { changed..., } 5=\text { now the best formulation } \\
\text { and may not be changed. }\end{array}$ \\
\hline & & $\begin{array}{l}\text { Would you strongly agree, agree, disagree, } \\
\text { or strongly disagree with the following } \\
\text { statements: }\end{array}$ \\
\hline
\end{tabular}




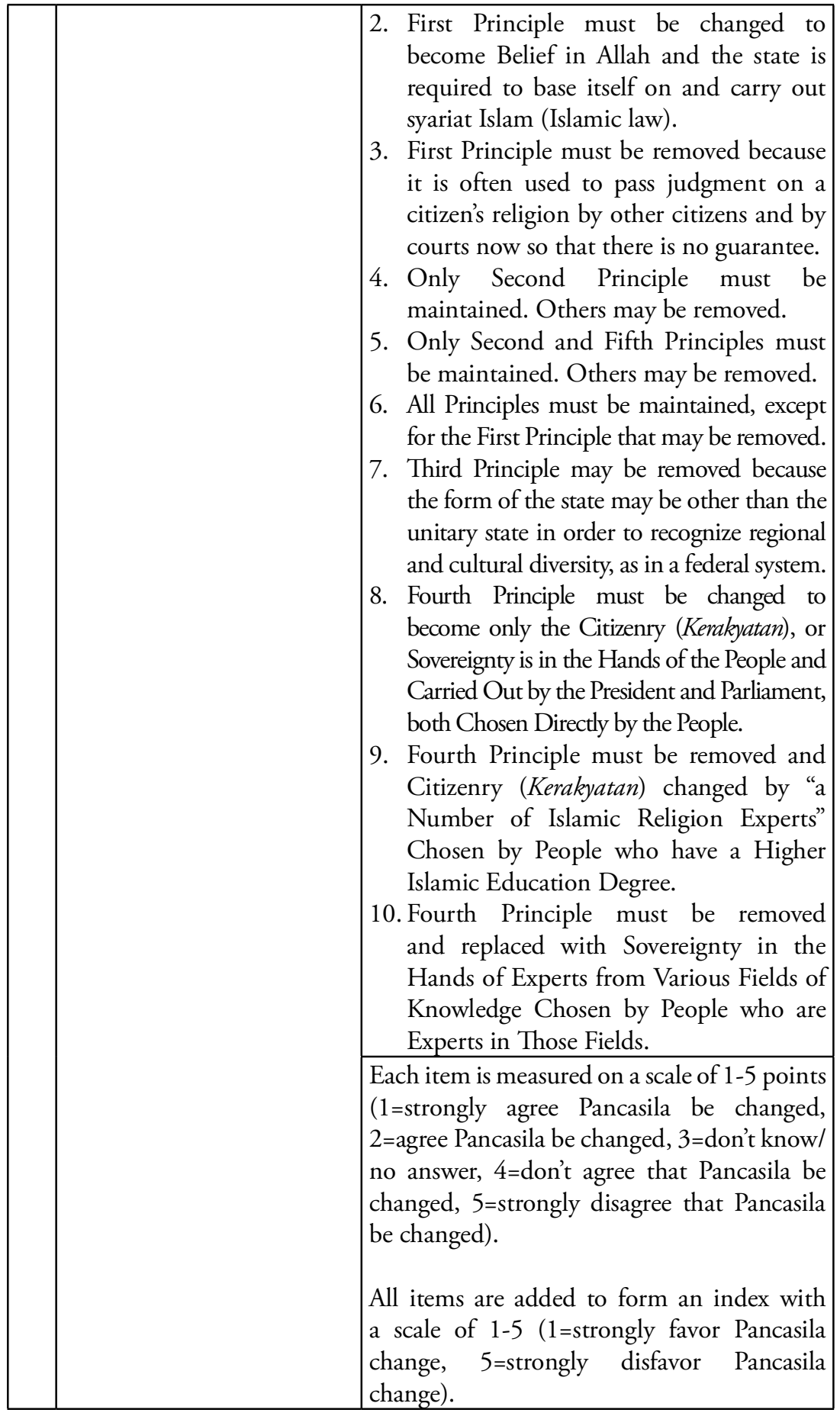




\begin{tabular}{|c|c|c|}
\hline 12 & Voting & $\begin{array}{l}\text { Did you vote in the last national legislative } \\
\text { election in } 2014 \text { ? } \\
\text { Yes }=1 \text {, no }=0 \text {. }\end{array}$ \\
\hline 13 & Civic engagement & $\begin{array}{l}\text { Are you an active member, non-active } \\
\text { member, or not a member of the following } \\
\text { social organizations, associations, groups, or } \\
\text { clubs? Active member and non-active member } \\
=1 \text {, non-member = 0. The organizations } \\
\text { are: Nahdlatul Ulama, Muhammadiyah, } \\
\text { PERSIS, FPI, majlis taklim, labor union, } \\
\text { farmers or fishers association, sports clubs, } \\
\text { cultural clubs, youth organizations, business } \\
\text { associations. A 0-1 point additive scale } \\
\text { is constructed from the items to form an } \\
\text { overall civic engagement index. For religious } \\
\text { civic engagement, only the relevant religious } \\
\text { group memberships are included to form } \\
\text { the index of Muslim civic engagement. The } \\
\text { non-religious civic engagement index only } \\
\text { includes the non-religious items. }\end{array}$ \\
\hline 14 & Political engagement & $\begin{array}{l}\text { How interested are you in politics? Very } \\
\text { interested }=5 \text {, somewhat interested }=4 \text {, don't } \\
\text { know }=3 \text {, not interested }=2 \text {, not interested } \\
\text { at all }=1 \text {. How often do you discuss politics } \\
\text { or governmental issues with friends or other } \\
\text { people? Very often }=5 \text {, somewhat often }=4 \text {, } \\
\text { don't know }=3 \text {, not often }=2 \text {, never }=1 \text {. How } \\
\text { often do you follow political or governmental } \\
\text { news via the following media: TV, newspaper, } \\
\text { radio, internet or social media? Every day = } \\
5 \text {, several times a week }=4 \text {, once a week }=3 \text {, } \\
\text { very rarely }=2 \text {, never }=1 \text {. An additive scale } \\
\text { was constructed from the items to form an } \\
\text { index of political engagement. }\end{array}$ \\
\hline 15 & $\begin{array}{l}\text { Political economy, law } \\
\text { and order, and security } \\
\text { conditions }\end{array}$ & $\begin{array}{l}\text { How do you rate the national political } \\
\text { condition nowadays? How do you rate the } \\
\text { national economic condition nowadays? } \\
\text { How do you rate the law and order condition } \\
\text { nowadays? How do you rate the national } \\
\text { security condition nowadays? Very bad }=1 \text {, } \\
\text { bad }=2 \text {, moderate or so and so }=3 \text {, good } \\
=4 \text {, very good }=5 \text {. An additive scale was } \\
\text { constructed to form an index of political } \\
\text { economy and security condition. }\end{array}$ \\
\hline
\end{tabular}


346 Saiful Mujani 


\section{Endnotes}

1. For discussion of democratic deconsolidation see Foa and Mounk (2016).

2. The most up-to-date engagement of Nahdlatul Ulama opinion on religious tolerance is that non-Muslims in Indonesia are not properly called "infidels." (BBC News Indonesia 2019)

3. In the field of Indonesian studies, and among Indonesian elites, Pancasila is usually called an ideology. I frame Pancasila as an institution, based on the institutional approach in which ideas and ideology are framed within institutions. This enables us to locate it in a wider debate about the importance of institutions in socio-political analysis.

4. Factor analysis of the 6 items of tolerance indicates that tolerance consists of two dimensions: religious and political. Two separate indexes were therefore constructed. The Muslim religious tolerance index consists of two items (prayer and building a house of worship) (Cronbach's Alpha 0.82 ). The religion based political tolerance index consists of four items (tolerant toward a non-Muslim to be president, vice president, governor, mayor, and district head (Cronbach's Alpha 0.97). However, for a general picture of tolerance, a third index, religio-political tolerance, was constructed by adding the two indexes (Cronbach's Alpha is 0.67 ). The three indexes are 1-3 point scales: closer to 1 indicates more intolerant and to 3 more tolerant. Indonesian Muslims are tolerant toward non-Muslims who conduct religious rituals or prayers in their neigborhood (mean $=2.167$ on a $1-3$ point scale). They are not tolerant toward non-Muslims who build houses of worship or shrines such as churches, chapels, temples, etc., near their neighborhoood $($ mean $=1.900)$. They tend to be more intolerant toward non-Muslims who hold strategic public offices such as president, vice-president, governor, or mayor (mean $=1.746$. Table 1$)$. The range of $1-3$ points is probably too small to understand the different attitudes. Frequencies are more helpful: $52.2 \%$ of Muslims do not mind if nonMuslims conduct collective rituals or prayers in their neighborhood; a smaller proportion of Muslims tolerate non-Muslims who build places of worship in their neighborhood (38.4\%). A majority of Muslims are intolerant toward non-Muslims who hold strategic public offices such as president $(62.8 \%)$, vice-president $(59,6 \%)$, governor $(56,1 \%)$, or mayor (55.6\%). See Appendix 1 for detailed measures and wordings concerning tolerance.

5. The index was constructed from a 1-4 point scale of ten items. Cronbach Alpha is 0.940.

6. The state electively accepts five religions only: Islam, Christianity, Hinduism, Buddhism, and Confucianism. Other religions are not officially accepted. Confucianism is not a religion but it is treated as religion.

7. The index is constructed from a 1-4 point scale of 8 items. Cronbach Alpha is 0.87. A score closer to 1 means weaker commitment and closer to 4 a stronger commitment to democratic values. See Appendix 3.

8. The index is an additive scale of membership in 12 social organizations $(0=$ non-member, $1=$ member).

9. The index of political engagement is a 1-5 point scale constructed from three items: intensity of political discussion, follow political news via various mass media and social media, and political interest (Cronbach Alpha is 0.688).

10. Coding for voter turnout: $1=$ vote, $0=$ not vote. The official turnout number in the last legislative election (2014) released by the Election Commission is lower: 75,41\%. In bivariate and multivariate statistics below, weighting of the variable, based on the Commission's report, was conducted to determine if the result in the analysis is significantly different. The result shows that they are not significantly different.

11. Index of national political economy, law and order, and security conditions is a $1-5$ point 
scale constructed from four batteries: national economic condition, national political condition, law and order in general, and national security. Score 1 means very bad, 3 moderate or average, 5 very good. Cronbach Alpha is 0.728 .

12. See endnote 4.

13. About the positive contribution of NU see Ramage (1995), and of NU relative to Muhammadiyah or Persis, see Menchik (2016).

14. All multivariate analyses in this study include only independent variables that in the bivariate statistics (Table 2) significantly correlate with religious, religion based political, or overall religio-political tolerance. The strength of impacts of one independent variable relative to other independent variables is based on standardized regression coeffients (Beta) which are not reported in the tables due to limited space. They are available from the author.

\section{Bibliography}

Almond, Gabriel A, and Sidney Verba. 1963. The Civic Culture: Political Attitudes and Democracy in Five Nations. Princeton, N.J: Princeton University Press.

Anderson, Benedict. 1972. "The Idea of Power in Javanese Culture." In Culture and Politics in Indonesia, ed. Claire Holt. Ithaca, N.Y: Cornell University Press.

Aspinall, Edward, and Eve Warburton. 2017. "Indonesia: The Dangers of Democratic Regression.” In Atlantis Press.

BBC News Indonesia. 2017. "Sidang Al Maidah: Dua tahun penjara untuk Ahok, langsung ditahan.” BBC News Indonesia. https://www.bbc.com/indonesia/ indonesia-39853373 (April 9, 2019).

2019. "Apakah sebaiknya istilah 'kafir' tidak lagi dipakai oleh komunitas Muslim?" BBC News Indonesia. https://www.bbc.com/indonesia/ indonesia-47431741 (April 9, 2019).

Beatty, K. M., and O. Walter. 1984. "Religious Preference and Practice: Reevaluating Their Impact on Political Tolerance.” Public Opinion Quarterly 48(1B): 318-29.

Cigler, Allan, and Mark R. Joslyn. 2002. "The Extensiveness of Group Membership and Social Capital: The Impact on Political Tolerance Attitudes." Political Research Quarterly 55(1): 7-25.

Côté, Rochelle R., and Bonnie H. Erickson. 2009. "Untangling the Roots of Tolerance: How Forms of Social Capital Shape Attitudes Toward Ethnic Minorities and Immigrants." American Behavioral Scientist 52(12): 1664-89.

Dahl, Robert Alan. 1971. Polyarchy: Participation and Opposition. New Haven: Yale University Press.

Duch, Raymond M., and James L. Gibson. 1992. “Putting Up With' Fascists in Western Europe: A Comparative, Cross-Level Analysis of Political Tolerance.” 
The Western Political Quarterly 45(1): 237-73.

Eisenstein, Marie A. 2006. "Rethinking the Relationship between Religion and Political Tolerance in the US." Political Behavior 28(4): 327-48.

Foa, Roberto Stefan, and Yascha Mounk. 2016. "The Democratic Disconnect." Journal of Democracy 27(3): 5-17.

Freedom House. 2018. "Freedom World 2018 Table of Country Scores." https://freedomhouse.org/report/freedom-world-2018-table-country-scores (September 3, 2019).

Geertz, Clifford. 1968. Islam Observed. Religious Development in Morocco and Indonesia. New Haven: Yale University Press.

Gibson, James L. 1998a. "A Sober Second Thought: An Experiment in Persuading Russians to Tolerate." American Journal of Political Science 42(3): 819-50.

. 1998b. "Putting Up With Fellow Russians: An Analysis of Political Tolerance in the Fledgling Russian Democracy." Political Research Quarterly 51(1): 37-68.

Hadiz, Vedi R. 2017. "Indonesia's Year of Democratic Setbacks: Towards a New Phase of Deepening Illiberalism?" Bulletin of Indonesian Economic Studies 53(3): 261-78.

Hall, Peter A., and Rosemary C. R. Taylor. 1996. "Political Science and the Three New Institutionalisms.” Political Studies 44(5): 936-57.

Huntington, Samuel P. 1997. The Clash of Civilizations and the Remaking of World Order. New York: Simon and Schuster.

Lewis, Bernard. 1998. The Political Language of Islam. Chicago: Chicago University Press. https://www.press.uchicago.edu/ucp/books/book/chicago/P/ bo3711632.html (September 3, 2019).

Liddle, R. William, and Saiful Mujani. 2013. "From Transition to Consolidation." In Democracy and Islam in Indonesia, eds. Mirjam Künkler and Alfred Stepan. Columbia University Press.

Lipset, Seymour Martin. 1959. "Some Social Requisites of Democracy: Economic Development and Political Legitimacy." The American Political Science Review 53(1): 69-105.

Locke, John, and Ian Shapiro. 2003. Two Treatises of Government and A Letter Concerning Toleration. eds. John Dunn and Ruth W. Grant. New Haven: Yale University Press.

Marcus, George E., John L. Sullivan, Elizabeth Theiss-Morse, and Sandra L. Wood. 1995. With Malice toward Some. How People Make Civil Liberties Judgments. New York, London: Cambridge University Press.

Menchik, Jeremy. 2016. Islam and Democracy in Indonesia: Tolerance without 
Liberalism. Cambridge: Cambridge University Press.

Menchik, Jeremy, and Thomas B. Pepinsky. 2018. Islam, Identity, and the Organizational Roots of Political Tolerance. Rochester, NY: Social Science Research Network. SSRN Scholarly Paper.

Mietzner, Marcus. 2018. "Fighting Illiberalism with Illiberalism: Islamist Populism and Democratic Deconsolidation in Indonesia." Pacific Affairs 91(2): 261-82.

Mietzner, Marcus, and Burhanuddin Muhtadi. 2018. "Explaining the 2016 Islamist Mobilisation in Indonesia: Religious Intolerance, Militant Groups and the Politics of Accommodation." Asian Studies Review 42(3): 479-97.

Mietzner, Marcus, Burhanuddin Muhtadi, and Rizka Halida. 2018. "Entrepreneurs of Grievance: Drivers and Effects of Indonesia's Islamist Mobilization." Bijdragen tot de Taal-, Land-en Volkenkunde 174(2-3): 159-87.

Milligan, Scott, Robert Andersen, and Robert Brym. 2014. "Assessing Variation in Tolerance in 23 Muslim-Majority and Western Countries." Canadian Review of Sociology/Revue canadienne de sociologie 51(3): 239-61.

Mujani, Saiful. 2003. "Religious Democrats: Democratic Culture and Muslim Political Participation in Post-Suharto Indonesia." Ph.D Thesis. The Ohio State University.

2007. Muslim Demokrat: Islam, Budaya Demokrasi, Dan Partisipasi Politik Di Indonesia Pasca Orde Baru. Jakarta: Gramedia Pustaka Utama.

Norris, Pippa, and Ronald Inglehart. 2011. Sacred and Secular: Religion and Politics Worldwide. New York: Cambridge University Press.

North, Douglass C., and Barry R. Weingast. 1989. "Constitutions and Commitment: The Evolution of Institutions Governing Public Choice in Seventeenth-Century England." The Journal of Economic History 49(4): 80332.

Pepinsky, Thomas B., R. William Liddle, and Saiful Mujani. 2018. Piety and Public Opinion: Understanding Indonesian Islam. Oxford: Oxford University Press.

PPIM UIN Jakarta. 2016. “Guru Agama Makin Tak Toleran.” PPIM UIN Jakarta. https:/ppim.uinjkt.ac.id/penelitian/guru-agama-makin-tak-toleran/.

Putnam, Robert D. 1993. Making Democracy Work. Princeton, NJ: Princeton Univ. Press.

Ramage, Douglas E. 1995. Politics in Indonesia: Democracy, Islam and the Ideology of Tolerance. New York and London: Routledge.

Sullivan, John L., James Piereson, and George E. Marcus. 1982. Political Tolerance and American Democracy. Chicago: University of Chicago Press.

Tempo.co. 2018. "Setara Institut: Intoleransi Terhadap Keyakinan Meningkat." 
Tempo. https://nasional.tempo.co/read/1118802/setara-institut-intoleransiterhadap-keyakinan-meningkat (April 9, 2019).

“Tolerance." Oxford Dictionaries. https://en.oxforddictionaries.com/definition/ tolerance (March 3, 2019).

Williams, Michael R., and Aaron P. Jackson. 2015. "A New Definition of Tolerance." Issues in Religion and Psychotherapy 37(1): 1-5.

Wise, Jasmine, and Robyn Driskell. 2017. "Tolerance Within Community: Does Social Capital Affect Tolerance?” Social Indicators Research 134(2): 607-29.

Saiful Mujani, Department of Political Science, Syarif Hidayatullah State Islamic University (UIN) of Jakarta, Indonesia. Email: sm@saifulmujani. com. 


\section{Guidelines}

\section{Submission of Articles}

tudia Islamika, published three times a year since 1994, is a bilingual (English and Arabic), peer-reviewed journal, and specializes in Indonesian Islamic studies in particular and Southeast Asian Islamic studies in general. The aim is to provide readers with a better understanding of Indonesia and Southeast Asia's Muslim history and present developments through the publication of articles, research reports, and book reviews.

The journal invites scholars and experts working in all disciplines in the humanities and social sciences pertaining to Islam or Muslim societies. Articles should be original, research-based, unpublished and not under review for possible publication in other journals. All submitted papers are subject to review of the editors, editorial board, and blind reviewers. Submissions that violate our guidelines on formatting or length will be rejected without review.

Articles should be written in American English between approximately 10.000-15.000 words including text, all tables and figures, notes, references, and appendices intended for publication. All submission must include 150 words abstract and 5 keywords. Quotations, passages, and words in local or foreign languages should 
be translated into English. Studia Islamika accepts only electronic submissions. All manuscripts should be sent in Ms. Word to: http:// journal.uinjkt.ac.id/index.php/studia-islamika.

All notes must appear in the text as citations. A citation usually requires only the last name of the author(s), year of publication, and (sometimes) page numbers. For example: (Hefner 2009a, 45; Geertz 1966, 114). Explanatory footnotes may be included but should not be used for simple citations. All works cited must appear in the reference list at the end of the article. In matter of bibliographical style, Studia Islamika follows the American Political Science Association (APSA) manual style, such as below:

1. Hefner, Robert. 2009a. "Introduction: The Political Cultures of Islamic Education in Southeast Asia," in Making Modern Muslims: The Politics of Islamic Education in Southeast Asia, ed. Robert Hefner, Honolulu: University of Hawai'i Press.

2. Booth, Anne. 1988. "Living Standards and the Distribution of Income in Colonial Indonesia: A Review of the Evidence." Journal of Southeast Asian Studies 19(2): 310-34.

3. Feener, Michael R., and Mark E. Cammack, eds. 2007. Islamic Law in Contemporary Indonesia: Ideas and Institutions. Cambridge: Islamic Legal Studies Program.

4. Wahid, Din. 2014. Nurturing Salafi Manhaj: A Study of Salafi Pesantrens in Contemporary Indonesia. PhD dissertation. Utrecht University.

5. Utriza, Ayang. 2008. "Mencari Model Kerukunan Antaragama." Kompas. March 19: 59.

6. Ms. Undhang-Undhang Banten, L.Or.5598, Leiden University.

7. Interview with K.H. Sahal Mahfudz, Kajen, Pati, June $11^{\text {th }}$, 2007.

Arabic romanization should be written as follows:

Letters: ', $b, t, t h, j, h, k h, d, d h, r, z, s, s h, s, d, t, z, ', g h, f, q, l$, $m, n, h, w, y$. Short vowels: $a, i, u$. long vowels: $\bar{a}, \overline{\mathrm{i}}, \overline{\mathrm{u}}$. Diphthongs: $a w$, ay. Tà marbūtāa: t. Article: al-. For detail information on Arabic Romanization, please refer the transliteration system of the Library of Congress (LC) Guidelines. 
ستوديا إسلاميكا (ISSN 0215-0492; E-ISSN: 2355-6145) مجلة علمية دولية محكمة تصدر عن مركز دراسات الإسلام والمجتمع (PPIM) بجامعة شريف هداية الله الإسلامية الحكومية بجاكرتا، تعنى بدراسة الإسلام في إندونيسيا خاصة وفي جنوب شرقي آسيا عامة. وتستهدف المجلة نشر البحوث العلمية الأصيلة والقضايا المعاصرة حول الموضوع، كما ترحب بإسهامات الباحثين أصحاب التخصصات ذات الصلة. وتخضع جميع الأبحاث المقدمة للمجلة للتحكيم من قبل لجنة مختصة.

تم اعتماد ستوديا إسلاميكا من قبل وزارة البحوث والتكنولوجيا والتعليم العالي بجمهورية إندونيسيا باعتبارها دورية علمية (رقم القرار: 32a/E/KPT/2017).

ستوديا إسلاميكا عضو في CrossRef (الإحالات الثابتة في الأدبيات الأكاديمية) منذ ع ا • ب، وبالتالي فإن جميع المقالات التي نشرتا مرقمة حسب معرّف الوثيقة الرقمية (DOI). ستوديا إسلاميكا بجلة مفهرسة في سكوبس (Scopus) منذ .ب مايو 0 . ب.

$$
\begin{aligned}
& \text { قيمة الاشتر الك السنوي خارج إندونيسيا: }
\end{aligned}
$$

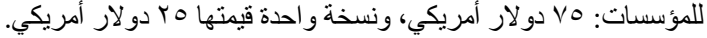

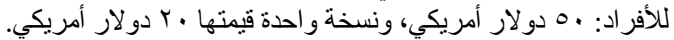

$$
\begin{aligned}
& \text { والقيمة لا تشمل نفقة الإرسال بالبريد الجوي. ونسي. }
\end{aligned}
$$

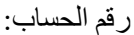

$$
\begin{aligned}
& \text { خارج إندونيسيا (دولار أمريكي): ابن }
\end{aligned}
$$

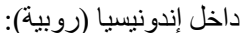

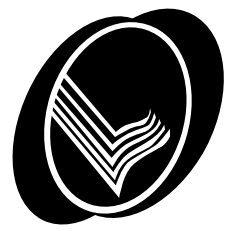




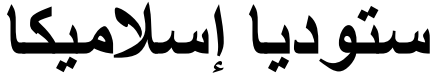 \\ مجلة إندونيسيا للار اسات الإسلامية}

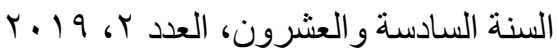

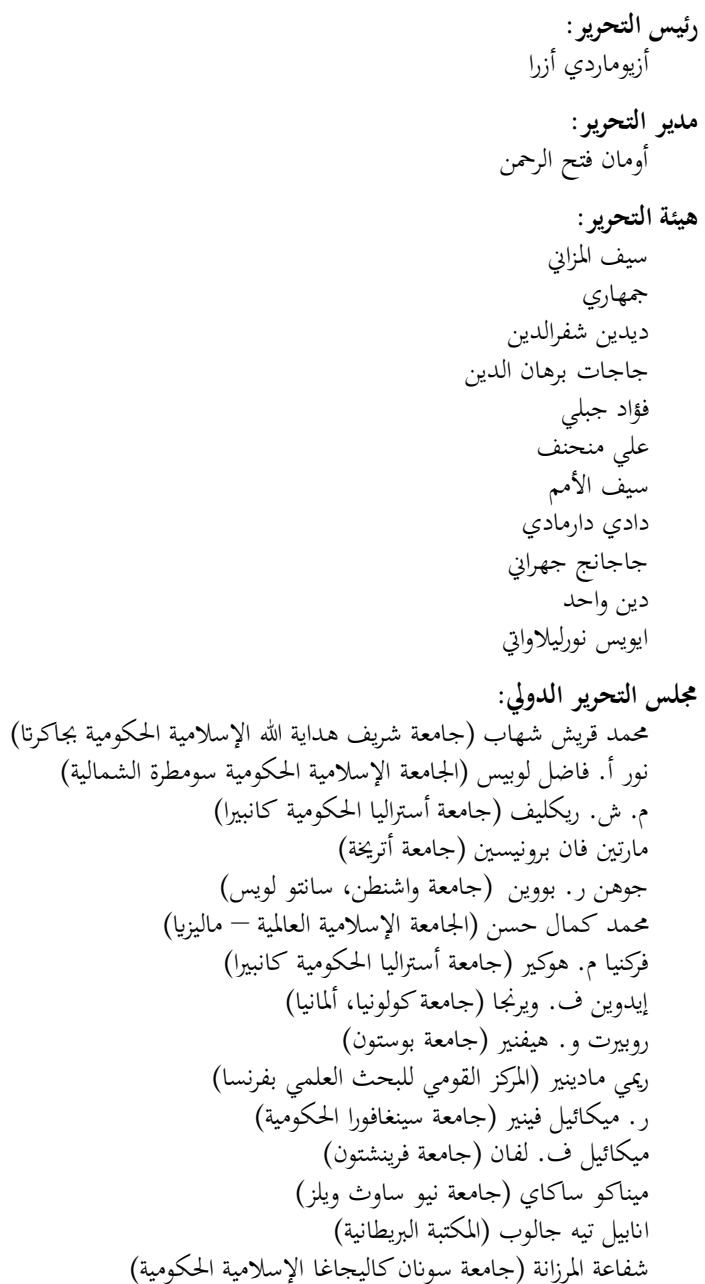

مساعد هيئة التحوير:

تيستريونو

محمد نداء فضلان

رنغكا إيكا سافوترا

عبد الله مولاني

مراجعة اللغة الإنجليزية:

بنيمن ج. فريمان الإنيليزة

دانيل فتريون

موسى بتول

مراجعة اللغة العربية:

توباغوس أدي أسناوي

أحمدي عثمان

تصميم الغلاف:

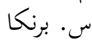





\section{لالتوايا السال|مسيا}




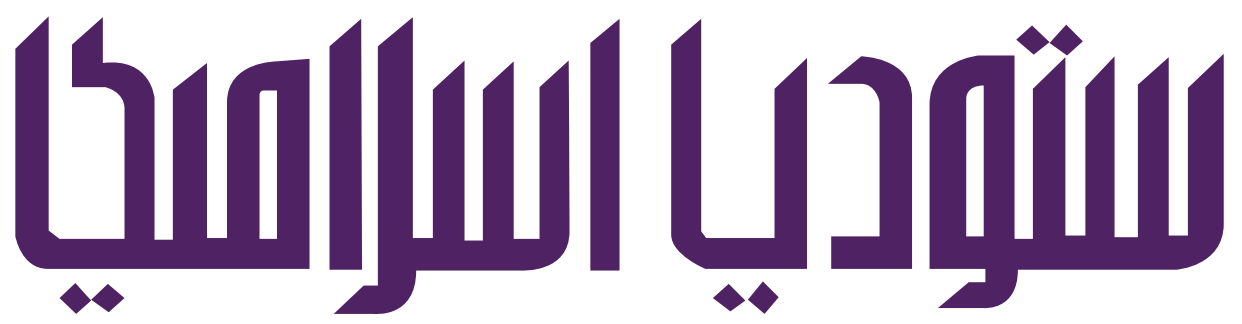

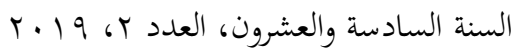

بحلة إندونيسية للدراسات الإسلامية

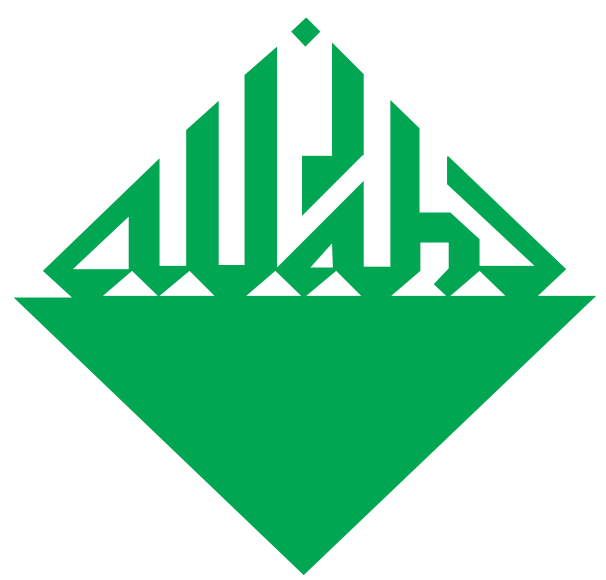

تمتليق نغرونيا لمسلميه بيغاياهان بياليه:

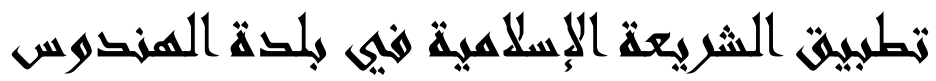

محمد عارف 